\title{
C-Kit Ligand Promotes Mast Cell Infection by Toxoplasma gondii
}

\author{
Mohamed Bidri ${ }^{\mathrm{a}}$, Marc Conti ${ }^{\mathrm{b}}$, Naïma Hanoun ${ }^{\mathrm{c}}$, René Lai Kuen ${ }^{\mathrm{d}}$, Frédéric Feger ${ }^{\mathrm{a}}$, Zacharie \\ Taoufiq $^{\mathrm{b}}$, Michel Arock ${ }^{\mathrm{a}}$, Dominique Mazier ${ }^{\mathrm{b}}$ and Ioannis Vouldoukis*,b \\ ${ }^{a}$ Cellular and Molecular Hematology Department UPRES EA2509, Faculty of Pharmacy, 4, Avenue de l'Observatoire, \\ 75006 Paris, France \\ ${ }^{b}$ INSERM UMR S511, Immunobiologie Cellulaire et Moléculaire des Infections Parasitaires, CHU Pitié-Salpêtrière, \\ Université Pierre et Marie Curie-Paris6, 75013 Paris, France \\ ${ }^{c}$ INSERM U677, Biochimie Médicale, CHU Pitié-Salpêtrière, Université Pierre et Marie Curie-Paris6, 75013 Paris, \\ France \\ ${ }^{d}$ Electron Microscopy Department, Faculty of Pharmacy, 4, Avenue de l'Observatoire, 75006 Paris, France
}

\begin{abstract}
Biological functions of mast cells include a functional role in innate immunity against parasitic infections. Here, we demonstrated that mast cells could also play a role in the anti-microbial defenses regulation and might participate as a parasite reservoir. We observed that Toxoplasma gondii infected massively in vitro mouse bone marrow derived mast cells (BMMC), a mucosal mast cell (MMC) phenotype, followed by substantial cell lysis. This induced release of $\beta$ hexosaminidase, but not of preformed or neosynthesized TNF- $\alpha$. Culturing MMC in the presence of recombinant mouse stem cell factor (c-kit ligand) led to their maturation into connective tissue-like mast cells (CTMC), which T. gondii was able to adhere on and to infect more. $T$. gondii infection did not induce release of $\beta$-hexosaminidase and serotonin from BMMC. These results demonstrated that mast cells interact with $T$. gondii and are massively infected, especially after their maturation by c-kit ligand.
\end{abstract}

Keywords: Mast cells, Toxoplasma gondii, C-kit, TNF- $\alpha, \beta$-hexosaminidase.

\section{INTRODUCTION}

Cytokines derived from macrophages and $\mathrm{T}$ cells are known to play an important regulatory role in host defense and to control the susceptibility to microbial infection. IL-1$\alpha$, IL-6, IFN- $\gamma$, IL-12 and TNF- $\alpha$ are particularly involved in host protection against Toxoplasma gondii infection [1]. During $T$. gondii infection an important role for IFN- $\gamma$ and TNF- $\alpha$ has been proposed both in the development of the disease and the mobilization of efficient defense mechanisms [2-5]. Toxoplasma is an obligate intracellular parasite. Its attachment to the host cell is the first step required for the mechanism of invasion, and the second step is critical for its silent survival. Unfortunately, the process for the identification of parasite ligands and cell surface receptors remains incomplete [6,7].

Mast cell is the only cell type that stocks preformed TNF- $\alpha$ in their granules [8]. The rapid release of TNF- $\alpha$ is crucial during $T$. gondii infection since it can exert a direct cytotoxic effect on microorganisms and an indirect effect by recruitment of phagocytic cells at the sites of infection [5]. Mast cells are found in relatively large number of adjacent to blood or lymphatic vessels but are most prominent immediately beneath the epithelial surface of the skin and the

*Address correspondence to the author at the INSERM UMR S511, Immunobiologie Cellulaire et Moléculaire des Infections Parasitaires, Université Pierre et Marie Curie-Paris6, CHU-Pitié-Salpêtrière, 91 bd de l'Hôpital, 75013 Paris, France; Tel: 33 (0)1 407781 09; Fax: 33 (0)1 458388 58;

E-mail: vouldouk@chups.jussieu.fr mucosa of the genitourinary, gastrointestinal, and respiratory tracts [9-11]. Moreover, mast cells release a large number of preformed mediators and produce neosynthezised mediators against external stimuli. In addition to inflammatory factors such as biogenic amines, leukotrienes and prostaglandins, mast cells produce and release a large panel of cytokines such as IL-1, IL-2, IL-3, IL-4, IL-5, IL-6, IL-8, IL-10, IL-12, IL-13, IFN- $\gamma$, TNF- $\alpha$, GM-CSF, MIP- $1 \alpha$, MIP- $1 \alpha$ and TGF$\beta[9,12]$. There is considerable evidence that mast cells recognize and react to a wide range of microorganisms or their products.

Stem cell factor (SCF), also termed Kit ligand, steel factor or mast cell growth factor is the ligand of the c-kit protooncogene product [13]. Therefore, SCF has been first described as a pluripotent growth factor involved in the early stages of haematopoiesis. Recently, it has been described to be also implicated in inflammatory processes [14].

Infection with $T$. gondii is acquired through the oral route by ingestion of undercooked or raw meat containing cysts of the parasite or through ingestion of water or food contaminated with cysts or oocysts. Following ingestion, sporozoites are released from cysts and rapidly invade the intestinal mucosa and convert into tachyzoites.

These observations suggested that mast cells may represent one of the first inflammatory cells encountered by an invading pathogen. Mast cells can exert cytotoxic activity against various pathogens, such as Schistosoma mansonii [15], Leishmania parasites [16,17], Escherichia coli [18] and 
Klebsiella pneumoniae [19], but their role against $T$. gondii infection remains poorly studied.

For this reason, we first studied the interaction between the mucosal mast cells (MMC) and T. gondii parasites and we analysed: 1) the possibility of MMC to phagocytose $T$. gondii, and 2) the role of preformed mediators (biogenic amines, TNF- $\alpha$ ) during in vitro co-incubation. We also studied the interaction between MMC after their maturation into connective tissue-like cells (CTMC) and T. gondii.

\section{MATERIALS AND METHODOLOGY}

\section{Mast Cell Cultures}

Bone marrow-derived mast cells (BMMC) were obtained from femurs of 2-months-old male BALB/c mice (IFFACREDO, L'arbresle, France) and were cultured at $37^{\circ} \mathrm{C}$ in a humidified atmosphere containing $5 \% \mathrm{CO}_{2}$ at a starting density of $3.10^{5}$ cells/ml in RPMI-1640 medium supplemented with L-glutamine, penicillin, streptomycin, 10\% FCS (complet medium) (all from Gibco Laboratories) and $2 \mathrm{ng} / \mathrm{ml}$ murine recombinant IL-3 (rIL-3; Immugenex, Los Angeles, CA). The medium was renewed every 5 to 7 days. After 28 days in culture, a sample of the cell suspension was stained with toluidine blue solution $(0,1 \%$ in $50 \%$ ethanol; $\mathrm{pH} 3,5)$. More than $98 \%$ of the cells used were identified as mast cells by the presence of metachromatic granules. These cell cultures presented the mucosal phenotype and were then used for subsequent experiments as pure mucosal mast cell populations. Mast cells obtained after a 4-weeks culture period in the presence of r-IL-3 were further cultured for 14 days in the presence of $40 \mathrm{ng} / \mathrm{ml}$ mouse recombinant c-kit ligand (Amgen, Thousand Oaks, CA). The differentiation into connective tissue mast cells and the mast cell phenotype were monitored by toluidine blue and alcian blue-safranine (ABS) staining [20, 21].

\section{Toxoplasma gondii Isolation}

Virulent $T$. gondii RH strain, maintained in Balb/c mice by intraperitoneal passage was isolated by peritoneal lavage following filtration. The $\mathrm{RH}$ strain never induces cystic forms in mice and kill mouse after 3 to 4 days. Tachyzoites were used in our studies and their viability was controled by trypan blue dye exclusion and only preparations with $>95 \%$ viable parasite were used. In our experiments Balb/c mice (IFFA-CREDO) were used at 6 to 8 weeks of age. During experimental protocols, all mice were maintained in specificpathogen-free facilities.

\section{Co-Culture of BMMC with T. gondii Parasites}

To determine the infectivity and the interactions between mast cells and $T$. gondii parasites, BMMC cultures $\left(10^{6}\right.$ cells $\left./ \mathrm{ml}\right)$ were exposed to $T$. gondii tachyzoites at various ratios of parasites per cell and incubated in 24-multiwell culture plates with the complet medium at $37^{\circ} \mathrm{C}$ in humidified air, containing $5 \% \mathrm{CO} 2$. After various periods, the cocultures were examined by direct parasitological studies of May-Grunwald Giemsa (MGG) stained cytospin preparations. The level of direct interactions between mast cells and T. gondii and the percentage of intracellular infection was evaluated microscopically by examining over 500 mast cells in three separate experiments.

\section{Electron Microscopy}

For morphologic studies by transmission electron microscopy (TEM), pellets of infected mast cells at different periods of culture were fixed in $2 \%$ glutaraldehyde and 0.1 M sodium cacodylate buffer, at PH 7.4. After glutaraldehyde fixation, the samples were processed for transmission electron microscopy.

\section{Mediators Release by Mast Cells}

For the measurement of $\beta$-hexosaminidase and TNF- $\alpha$ release, BMMC cultures $\left(10^{6}\right.$ cells $\left./ \mathrm{ml}\right)$ were exposed (in $24-$ multiwell culture plates) to $T$. gondii tachyzoites at a ratio of 1 and 4 parasites per cell and incubated in white RPMI 1640 (without red phenol) plus $1 \%$ bovine serum albumin (BSA). The reaction mixtures were centrifuged at $500 \mathrm{~g}$ for $10 \mathrm{~min}$ at $4^{\circ} \mathrm{C}$. The supernatants and pellets were collected at different time of coculture and stored at $-80^{\circ} \mathrm{C}$ until assay. In addition, to determine maximal mediator release ability of BMMC after IgE-immune complex stimulation, cells (one million per $\mathrm{ml}$ in RPMI-1640 devoid of phenol red) were optimally sensitised by incubation at $37^{\circ} \mathrm{C}$ for $60 \mathrm{~min}$ with $10 \mu \mathrm{g} / \mathrm{ml}$ of mouse monoclonal IgE directed against Dinitrophenyl (DNP; ICN Biomedicals, Costa Mesa, CA). The cells were then washed twice, and resuspended at $10^{6}$ cells $/ \mathrm{ml}$ in the same medium, then seeded in 24-well plates $(1 \mathrm{ml}$ per well). At this time, $10 \mathrm{ng}$ of DNP-BSA (Calbiochem, La Jolla, CA) were added in each well for $60 \mathrm{~min}$.

\section{$\boldsymbol{\beta}$-Hexosaminidase Assay}

$\beta$-hexosaminidase release was measured after coculture of BMMC with $T$. gondii at $37^{\circ} \mathrm{C}$ as described above. Briefly, $\beta$-hexosaminidase was measured in the supernatants and extracts of sonicated mast cell sediments after $40 \mathrm{~min}, 4$, 24 and 48 hours of culture by hydrolysis of p-nitrophenyl-2acetamido-2-deoxy- $\beta$-D glucopyranoside exactly as described elsewhere $[22,23]$. The percentage of release of $\beta$ hexosaminidase was calculated by the following formula: net percent release $=\left[S-S^{\text {control }}\right] /\left[(S+P)-S^{\text {control }}\right] \times 100$, where $\mathrm{S}$ is the mediator content of supernatant cells, $\mathrm{P}$ is the mediator content of pellet of stimulated cells, and $S^{\text {control }}$ is the mediator content of supernatant of unstimulated cells.

\section{Serotonin Assay}

Cell supernatants $(250 \mu \mathrm{l}$ aliquots) were supplemented with $5 \%$ (v/v) $\mathrm{HClO}_{4}, 0.05 \%(\mathrm{w} / \mathrm{v})\left(\mathrm{Na}_{2} \mathrm{~S}_{2} \mathrm{O}_{5}\right.$ and $0.05 \%$ $(\mathrm{w} / \mathrm{v})$ disodium ethylene diaminetetraacetic acid (EDTA), and the resulting precipitate was removed by centrifugation at $30000 \mathrm{~g}$ for $15 \mathrm{~min}$ at $4^{\circ} \mathrm{C}$. Clear supernatants were then neutralized by the addition $30 \mu \mathrm{l}$ of $2 \mathrm{M} \mathrm{KH}_{2} \mathrm{PO}_{4} / \mathrm{K}_{2} \mathrm{HPO}_{4}$, $\mathrm{pH} 7.4$ and supplemented with ascorbate oxidase $(0.01$ $\mathrm{mg} / \mathrm{ml}$, Boehring Manuhein Germany), before a second centrifugation as above to remove $\mathrm{KclO}_{4}$ precipitate. Aliquots $(10 \mu \mathrm{l})$ of resulting clear supernatants were injected directly into a high-performance liquid chromatography (HPLC) column (Ultrasphere IP, Beckman, Gagny, France; 25 x $0.46 \mathrm{~cm}, \mathrm{C} 18$ reversed-phase, particle size $5 \mu \mathrm{m}$ ) protected with a brownlee precolumn $(3 \mathrm{~cm}, 5 \mu \mathrm{m})$. The mobile phase (at a flow rate of $1 \mathrm{ml} / \mathrm{min}$ ) consisted of (in $\mathrm{mM}$ ): $\mathrm{KH}_{2} \mathrm{PO}_{4}$, 70; triethylamine, EDTA, 0.1; octane sulphonate, 1.25, and $16 \%$ methanol, adjusted to $\mathrm{pH} 3.02$ with solid citric acid [24]. Serotonin (5-hydroxytryptamine, 5 HT) eluted from the 


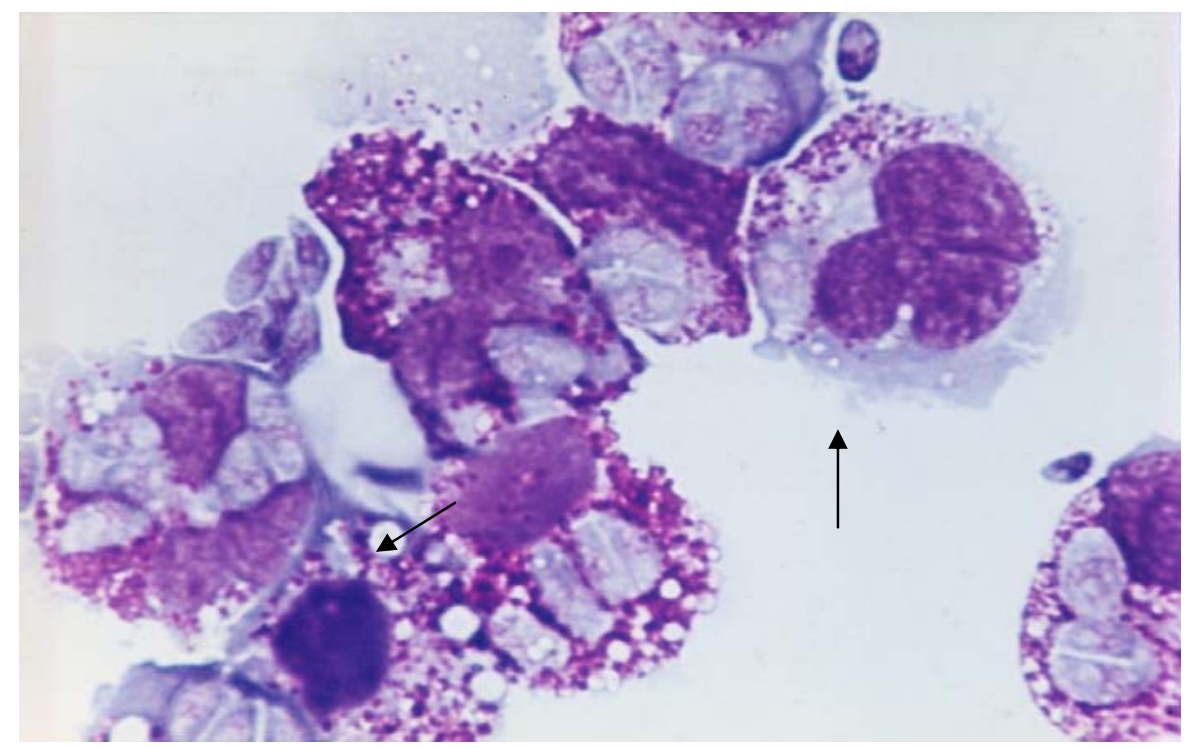

Fig. (1). Direct interactions between $T$. gondii and mast cells.

Co-cultures of BMMC $\left(10^{6}\right.$ cells $)$ with $T$. gondii $\left(10^{6}\right.$ parasites $)$ at $37^{\circ} \mathrm{C}-5 \% \mathrm{CO}_{2}$ show clear binding of multiple parasites on mast cell membrane (May-Grumwald Giesmsa staining, x 300). Intracellular T. gondii parasites (arrow) obtained after 1h of coculture with BMMC.

column (retention time $=32 \mathrm{~min}$ ) was monitored by an electrochemical detection system (ESA 5011, Bedford, USA) made of an analytical cell with dual coulometric monitoring electrodes $(+50 \mathrm{mV}$ and $+350 \mathrm{mV})$. The generated signal was integrated by a computing integrator (Millenium ${ }^{32}-$ Waters, Saint-Quentin-en-Yvelines, France). Quantitative determination of 5-HT was made by reference to appropriate external standards (10 pg - $10 \mathrm{ng}$ ) authentic 5 HT, (Sigma, Saint-Quentin Fallavia, France).

\section{TNF- $\alpha$ Assay}

TNF- $\alpha$ production was measured in the cell supernatants after 1, 3 and 6 hours of culture by a specific ELISA method (Mouse TNF- $\alpha$ ELISA Kit, Genzyme, Cambridge, MA). Results are expressed in $\mathrm{pg} / \mathrm{ml}$ and the detection limit of the assay is $15 \mathrm{pg} / \mathrm{ml}$.

\section{Statistical Analysis}

Data are reported as mean \pm SD of separate experiments. Differences were analyzed for significance $(\mathrm{p}<0.05)$ by Student's t test.

\section{RESULTS}

\section{T. gondii Infection of Mast Cells}

Rapidly, in less than 30 minutes, T. gondii parasites adhered to cultured mast cells. The percentage of BMMC bearing parasites on their membrane and the number of parasites bound on these cells increased with parasite cell ratio. Indeed, after one hour of coculture at a mast cell-parasite ratio of $1: 2$, more than $40 \%$ of the cells exhibited membrane bound $T$. gondii ( $4 \pm 3$ parasites per cell). Following this interaction, the parasite penetrates the cell through their microvilli and replicates in the cytoplasm (Fig. 1).

The percentage of mast cells infected by $T$. gondii (assessed by MGG staining) was $5 \pm 1 \%$ and $8 \pm 2 \%$ respectively for a ratio $1: 1$ and 1:2 after 1 hour of coculture. These percentages increased rapidely over one hour reaching, $16 \pm 6$ and $30 \pm 9$ after $4 \mathrm{~h}, 85 \pm 5$ and $94 \pm 4$ at 24 hours (respectively for the ratios 1:1 and 1:2). The percentage of infection and the average numbers of parasites per infected cell were increased significantly with the time of the coculture (Table $\mathbf{1}$ ).

Table 1. T. gondii in vitro infection of BMMC at different time points. In this table, we report the rate (\%) of infected mast cells and the number of tachyzoites per infected cell. Results represent the mean $\pm \mathrm{SD}$ of 500 cells, in three separate experiments

\begin{tabular}{|c|c|c|c|c|c|}
\hline Culture conditions & \multicolumn{3}{|c|}{ \% of infected cells } & \multicolumn{3}{c|}{ Number of tachyzoites per infected cell } \\
\hline & $\mathbf{1 h}$ & $\mathbf{4 h}$ & $\mathbf{2 4 h}$ & $\mathbf{1 ~ h}$ & $\mathbf{4 h}$ \\
\hline \hline $\begin{array}{c}\text { BMMC (IL-3) + T. gondii } \\
\text { (ratio 1:1) }\end{array}$ & $5 \pm 1$ & $16 \pm 6$ & $85 \pm 5$ & $1 \pm 1$ & $3 \pm 1$ \\
\hline $\begin{array}{c}\text { BMMC (IL-3) + T. gondii } \\
\text { (ratio 1:2) }\end{array}$ & $8 \pm 2$ & $30 \pm 9$ & $94 \pm 4$ & $1 \pm 1$ & $5 \pm 2$ \\
\hline
\end{tabular}


The adherence of parasites on mast cells and the number of mast cells infected were more important with long-term treatment of MMC with SCF, allowing them to differentiate into CTMC. The percentage of CTMC and MMC infected at 5 hours is respectively $18 \pm 7 \%$ and $27 \pm 8 \%$ with the ratio (1:1) and respectively $42 \pm 10 \%$ and $56 \pm 12 \%$ with the ratio (1:4) (Table 2).

Table 2. In vitro interaction between 2 sub-types of mast cells and $T$. gondii parasites after 5 hours of coculture. In this table, we report the rate $(\%)$ of infected mast cells. Results represent the mean $\pm S D$ of 500 cells, in three separate experiments

\begin{tabular}{|c|c|}
\hline Culture conditions & \% of infected cells 5 hours \\
\hline \hline $\begin{array}{c}\text { CTMC (IL-3) + T. gondii } \\
\text { (ratio 1:1) }\end{array}$ & $18 \pm 7$ \\
\hline $\begin{array}{c}\text { MMC (IL-3 + c-kit ligand) + T. gondii } \\
\text { (ratio 1:1) }\end{array}$ & $27 \pm 8$ \\
\hline $\begin{array}{c}\text { CTMC (IL-3) }+ \text { T. gondii } \\
\text { (ratio 1:4) }\end{array}$ & $42 \pm 10$ \\
\hline $\begin{array}{c}\text { MMC (IL-3 + c-kit ligand) }{ }^{\circ}+T . \text { gondii } \\
\text { (ratio 1:4) }\end{array}$ & $56 \pm 12$ \\
\hline
\end{tabular}

${ }^{\circ}$ Values significantly different from non stimulated with c-kit ligands BMMC $(\mathrm{p}<0,05)$.

The presence of parasites in the cytoplasm of mucosal mast cells was confirmed by transmission electron microscopy. The light microscopic examination showed areas of lysed cells, and the higher level of lysis was approximately obtained at 48 hours of co-culture with $10^{6}$ mast cells and $10^{6}$ parasites (date not shown). These data clearly demonstrate that all along the infectious process with Toxoplasma represent a putative important reservoir for parasites.

\section{Ultra-Structural Examination}

Rapidly, 10 minutes after co-culture, the tachyzoites adhered to the surface microvilli projections of the mucosal mast cells, and penetrated cells at apical site at approximately 30 minutes (Fig. 2a). After 6 hours, T.gondii replicated into mast cells (Fig. 2b), and the parasites occupied nearly all the cytoplasma and lysed in mast cells after 24 hours. Mast cell-induced T. gondii cytotoxic changes included a marked disruption of the surface membrane structures of the organisms, intracellular vacuolation were observed after 10 hours of coculture (Fig. 2c).

\section{Release of $\boldsymbol{\beta}$-Hexosaminidase}

The cell-membrane attachement of the parasite in mast cells induced a low release of $\beta$-hexosaminidase by BMMC after 60 minutes of culture (Fig. 3). The maturation of MMC into CTMC by c-kit ligand did not enhance the release of $\beta$ hexosaminidase (data not shown). Even though the level of $\beta$-hexosaminidase release was lower to that observed after triggering the high affinity receptor of $\operatorname{IgE}$ (FceRI), this time-dependent release of $\beta$-hexosaminidase is relevant. The release kinetic was similar to the lysis kinetic of the mast cells by $T$. gondii (Fig. 4). In addition, mast cells/T. gondii parasites interaction did not interfere with the release of $\beta$ hexosaminidase after ligation of FceRI receptors on these cells (Fig. 3).
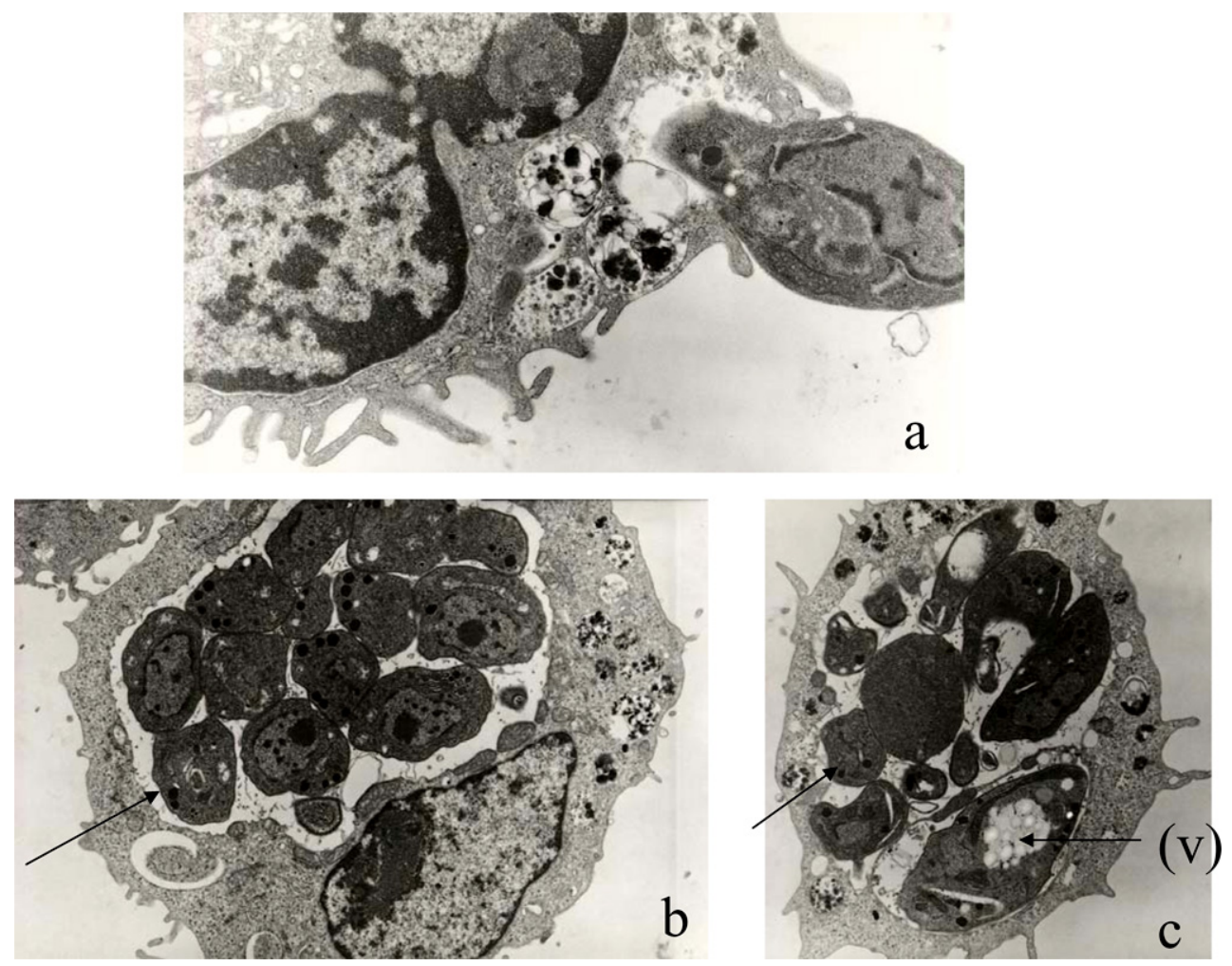

Fig. (2). Transmission electron microscopy examination of cross-section of BMMC showing: (a) the adherence of $T$. gondii to mast cell, (b) the internalization of the parasites and their proliferation, (c) mast cell-induced intracellular parasite cytotoxicity and vacuole formation in $T$. gondii are observed (V). 


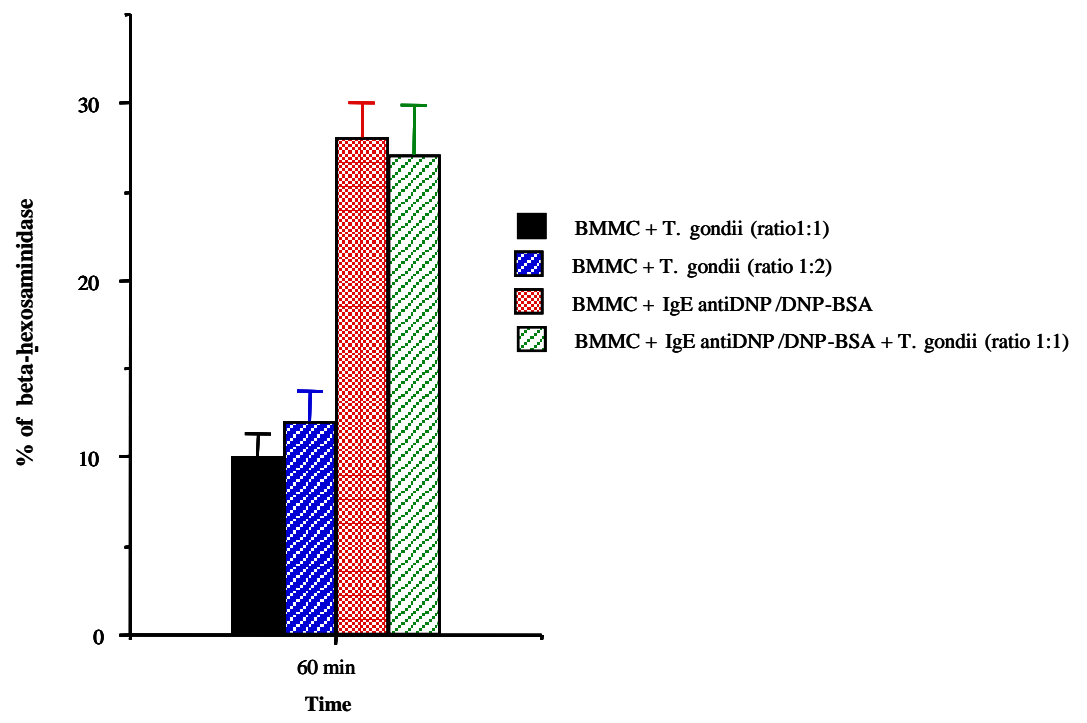

Fig. (3). Low-level degranulation of mast cells exposed in vitro to T. gondii.

The degranulation is appreciated by a $\beta$-hexosaminidase released by mast cells after $60 \mathrm{~min}$ and compared to maximal release obtained with optimal IgE antiDNP $(10 \mu \mathrm{g} / \mathrm{ml}) / \mathrm{DNP}-\mathrm{BSA}(10 \mathrm{ng} / \mathrm{ml})$, stimulation. Results represent the mean \pm SD of three separate experiments.

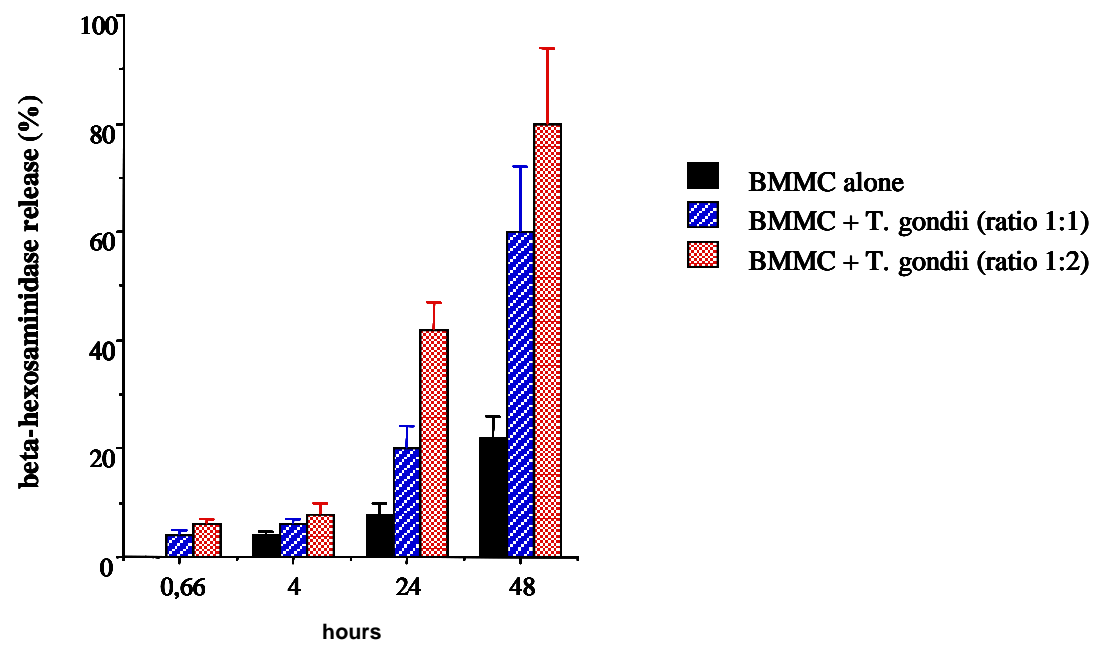

Fig. (4). Time-course released of $\beta$-hexosaminidase by BMMC $\left(10^{6}\right.$ cells $)$ exposed in vitro to T. gondii parasites at different ratio.

\section{Release of Serotonin (5-HT)}

Concomitantly to the release of $\beta$-hexosaminidase parasite/mast cell interaction did not induce the release of serotonin after 3 hours of co-culture. The maturation of MMC into CTMC by c-kit ligand did not enhance the release of serotonine by mast cells coculture with Toxoplasma parasites (Fig. 5). However, the treatment by c-kit ligand enhanced the intracellular amount of serotonin by these cells (1070ng/10 with CTMC cells compared to $610 \mathrm{ng} / 10^{6}$ with MMC cells).

\section{Release of TNF- $\alpha$}

Mast cells synthesize, store in granules and release continually a low amount of TNF- $\alpha$ and thus control the local immune homeostasis. We evaluated the effect of $T$. gondii binding to mast cells on this production. The coculture of BMMC with $T$. gondii parasites (ratio 1:1 and 1:2) did not induce a significant increase in secretion of TNF- $\alpha$ by these cells at $1 \mathrm{~h}, 3 \mathrm{~h}$ and $6 \mathrm{~h}$ (IgE anti DNP/DNP-BSA), compared to the amount of TNF- $\alpha$ constitutively released by mast cells at $24 \mathrm{~h}$ (Fig. 6).

\section{DISCUSSION}

The precise mechanisms by which mast cells could play a role during host invasion by Toxoplasma parasites are yet unknown. Recent data have evidenced a new role for these cells in innate immunity against bacteria and protozoan parasites, through their ability to be stimulated by their FceRI or directly by these infectious agents [25-27]. Upon activation, 


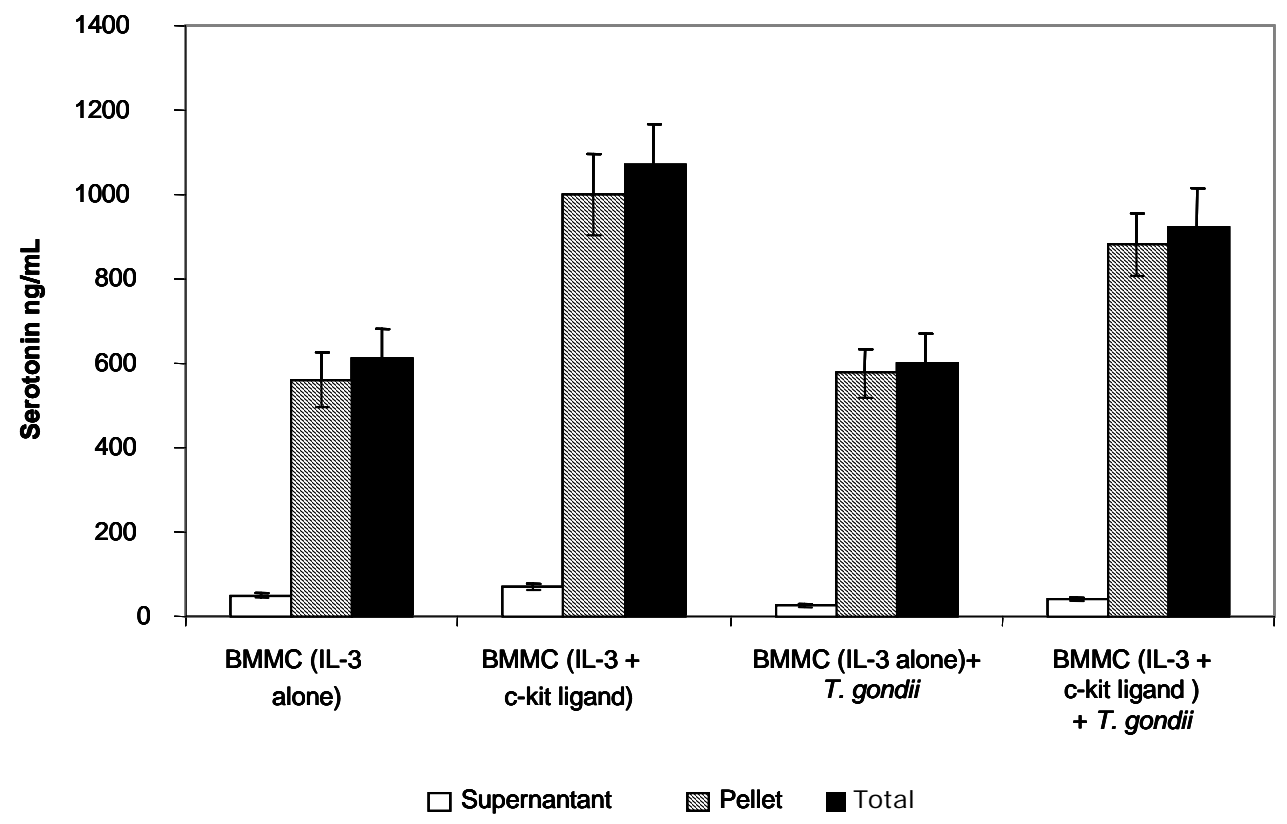

Fig. (5). The release of serotonin $(5-\mathrm{HT})$ by two sub-types of $\left(10^{6}\right)$ mast cells in co-culture with T. gondii $\left(10^{6}\right)$ parasites after 3 hours, mesured in supernatants and in the lysate pellet of cell preparations. Results represent the mean $\pm \mathrm{SD}$ of three separate experiments.

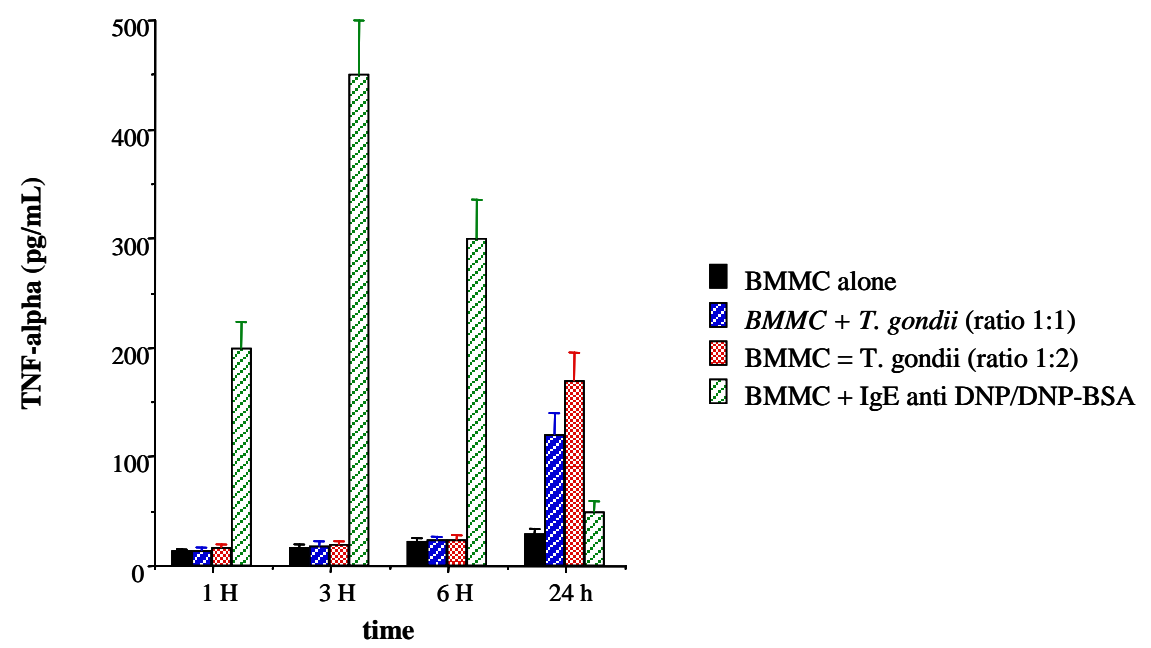

Fig. (6). Time-dependent release of TNF- $\alpha$ protein released by mast cells following in vitro exposure to T. gondii parasites as compared to that obtained after IgE/antigen stimulation. Results represent the mean \pm SD of three separate experiments in the culture supernatants of BMMC.

mast cells release, within minutes, preformed mediators stocked in granules such as histamine, $\beta$-hexosaminidase and TNF- $\alpha$. In addition, they are able to synthesize various cytokines, which account for long-term maintenance of the inflammatory response during allergic reactions [28, 29] and can take part in acquired immune responses against microorganisms [25-27].

We have previously demonstrated that Leishmania promastigotes adhere to mast cells and that a few parasites were phagocytosed and transformed into amastigotes by these cells [16], whereas, T. gondii invades these cells by an active process [30]. Moreover, Leishmania, an obligate intracellular parasite, can infect BMMC and induce the release of preformed mediators such as $\beta$-hexosaminidase and TNF- $\alpha$. In addition, this interaction induces the neosynthesis of TNF- $\alpha$ by BMMC [16]. In contrast, data from the present study, clearly demonstrate that another obligate intracellular parasite, $T$. gondii, induces a low release of $\beta$-hexosaminidase and does not induce a significant release of serotonin and TNF- $\alpha$ from BMMC. Moreover, Pelloux and coworkers [31] have shown that $T$. gondii infection does not induce a sig- 
nificant release of TNF- $\alpha$ from a human astrocytoma cell line after 1, 3, 6 and 24 hours of co-culture; although this cell line secretes constitutively TNF- $\alpha$. Nevertheless, tachyzoites does not inhibit the secretion of TNF- $\alpha$ by human astrocytoma cell line activated by phorbol ester (PMA).

Henderson and coworkers [32] have shown that rat peritoneal mast cell- $T$. gondii interaction induced the release of histamine (preformed mediator stocked in granules as same at $\beta$-hexosaminidase) by these cells. These authors have cocultured mature in vivo serosal mast cells and $T$. gondii with a higher ratio of parasites (1:6). To mimic this model, we have differentiated the in vitro MMC into CTMC by addition of c-kit ligand for 14 days. This maturation is objectived by the increase of the amount of serotonin $(5-\mathrm{HT})$ in these cells $\left(1070 \mathrm{ng} / 10^{6}\right.$ with CTMC compared to $610 \mathrm{ng} / 10^{6}$ with MMC). In our hands the interaction between CTMC and $T$. gondii did not enhance the release of $\beta$-hexosaminidase, but we have observed an increase of the parasite adherence on CTMC and of the number of infected cells, compared with MMC. In addition, the increase of the ratio parasite-mast cells does not enhance the release of $\beta$-hexosaminidase and serotonin (data not shown).

The discrepancies interactions between Leishmania and Toxoplasma towards mast cells are probably due to the difference of antigenic membrane profile on these two protozoans. Promastigotes of Leishmania species possess a major surface antigen, the glycoprotein gp63 kDa [33]. This major antigen is involved in macrophage binding, and can bind the fibronectin [34]. Similarily the major surface antigen of $T$. gondii (SAG-1 or P30) seems to be implicated in the adherence and invasion of various cells $[35,36]$. Fibronectin and laminin could be implicated in the adherence of Leishmania promastigotes to cells and laminin, but not fibronectin could be implicated in the invasion of cells by T. gondii. [37].

Mast cells express many membrane receptors, a large number of receptors for cytokines, immunoglobulins and complement receptors. IL-3-dependent murine BMMC could only adhere to laminin or fibronectin after activation with PMA or after FceRI aggregation, moreover, BMMC spontaneously adhered to vitronectin [38]. C-kit ligand factor was found to promote the adhesion of IL-3-dependent BMMC to fibronectin and lamilin [39-41].

We have observed that the percentage of infected mast cells with toxoplasma parasites increased and correlated with the number of parasites initially added to cells. The parasite replicated rapidly in mast cells, occupied the whole volume of these cells and lysed them. So, these cells release the whole amount of preformed TNF- $\alpha$ at 24hours (Fig. 6), whereas serotinin remains only detectable in the mast cell pellets (data not shown). The entirety of infected mast cells was lysed between 24 and 48 hours of co-culture, and all of T. gondii parasites remaining extracellular.

A possible mechanism for how $T$. gondii parasites trigger mast cell degranulation may be through the release of lysophospholipids from the tachyzoites apical organelles, termed rhoptries [42]. Indeed, lysophospholipids, specially phosphatidylserine, potentialise mast cell histamine secretion [43]. Moreover, lysophosphatidylserine specifically activates connective mast cells in vitro $[44,45]$ and in vivo but not mucosal mast cells [46]. Have shown that $T$. gondii induces the release of histamine and synthesis of LTB4 by rat peritoneal mast cells an in vivo "serosal mast cell" model. On the contrary we have observed a low release of $\beta$ hexosaminidase and poor low release of TNF- $\alpha$ and serotonin by a "mucosal mast cell" model, and the differentiation of these cells into serosal mast cells in vitro, did not enhance the release of $\beta$-hexosaminidase and serotonin. In addition, these cells serve as a major chemokines (CXCR2) and cytokines $(\mathrm{TNF}-\alpha)$ source involved in neutrophil recruitment [47] in the site of infection by T. gondii [48], and participate in the defense against microorganisms and protozoan parasites.

\section{CONCLUSION}

In this work, we demonstrated clearly that mast cells interact with $T$. gondii and that this interaction induces rapidly a high rate of infection and progressively lysis of mast cells. Finally, the increased adherence and infectivity of mast cells by $T$. gondii, is probably due to the expression of $\beta$ integrins on mast cells after their treatment by c-kit ligand. Such investigations about the interaction between these two elements are now currently in progress in our laboratory.

\section{ACKOWLEDGMENTS}

We would like to address special thanks to Pr Valérie Tricotet, Dr Domagoj Sabolovic, Pr Michel Hamon and Dr MD Aftabuddin for helpful discussions.

\section{REFERENCES}

[1] Khan IA, Matsuura T, Kasper LH. Interleukin-12 enhances murine survival against acute toxoplasmosis. Infect Immun 1994; 62(5): 1639-42.

[2] Bessieres MH, Swierczynski B, Cassaing S, et al. Role of IFNgamma, TNF-alpha, IL4 and IL10 in the regulation of experimental Toxoplasma gondii infection. J Eukaryot Microbiol 1997; 44(6): $87 \mathrm{~S}$.

[3] Jones TC, Bienz KA, Erb P. In vitro cultivation of Toxoplasma gondii cysts in astrocytes in the presence of gamma interferon. Infect Immun 1986; 51(1): 147-56.

[4] Yap GS, Scharton-Kersten T, Charest H, Sher A. Decreased resistance of TNF receptor p55- and p75-deficient mice to chronic toxoplasmosis despite normal activation of inducible nitric oxide synthase in vivo. J Immunol 1998; 160(3): 1340-5.

[5] Yap GS, Sher A. Cell-mediated immunity to Toxoplasma gondii: initiation, regulation and effector function. Immunobiology 1999; 201(2): 240-7.

[6] Sibley LD. Toxoplasma gondii: perfecting an intracellular life style. Traffic 2003; 4(9): 581-6.

[7] Carruthers V, Boothroyd JC. Pulling together: an integrated model of Toxoplasma cell invasion. Curr Opin Microbiol 2007; 10(1): 839.

[8] Okayama Y. Mast cell-derived cytokine expression induced via Fc receptors and Toll-like receptors. Chem Immunol Allergy 2005; 87: 101-10.

[9] Metcalfe DD, Baram D, Mekori YA. Mast cells. Physiol Rev 1997; 77(4): 1033-79.

[10] Okayama Y, Ra C, Saito H. Role of mast cells in airway remodeling. Curr Opin Immunol 2007; 19(6): 687-93.

[11] Wasserman SI. Mast cell-mediated inflammation in asthma. Ann Allergy 1989; 63(6 Pt 2): 546-50.

[12] Galli SJ, Wershil BK. Mouse mast cell cytokine production: role in cutaneous inflammatory and immunological responses. Exp Dermatol 1995; 4(4 Pt 2): 240-9.

[13] Huang E, Nocka K, Beier DR, et al. The hematopoietic growth factor KL is encoded by the Sl locus and is the ligand of the c-kit receptor, the gene product of the W locus. Cell 1990; 63(1): 22533. 
[14] Reber L, Da Silva CA, Frossard N. Stem cell factor and its receptor c-Kit as targets for inflammatory diseases. Eur J Pharmacol 2006; 533(1-3): 327-40.

[15] Henderson WR, Chi EY, Jong EC, Klebanoff SJ. Mast cellmediated toxicity to schistosomula of Schistosoma mansoni: potentiation by exogenous peroxidase. J Immunol 1986; 137(8): 2695-9.

[16] Bidri M, Vouldoukis I, Mossalayi MD, et al. Evidence for direct interaction between mast cells and Leishmania parasites. Parasite Immunol 1997; 19(10): 475-83.

[17] Von Stebut E. Immunology of cutaneous leishmaniasis: the role of mast cells, phagocytes and dendritic cells for protective immunity. Eur J Dermatol 2007; 17(2): 115-22.

[18] Arock M, Ross E, Lai-Kuen R, Averlant G, Gao Z, Abraham SN. Phagocytic and tumor necrosis factor alpha response of human mast cells following exposure to gram-negative and gram-positive bacteria. Infect Immun 1998; 66(12): 6030-4.

[19] Malaviya R, Ikeda T, Ross E, Abraham SN. Mast cell modulation of neutrophil influx and bacterial clearance at sites of infection through TNF-alpha. Nature 1996; 381(6577): 77-80.

[20] Bidri M, Ktorza S, Vouldoukis I, et al. Nitric oxide pathway is induced by Fc epsilon RI and up-regulated by stem cell factor in mouse mast cells. Eur J Immunol 1997; 27(11): 2907-13.

[21] Tsai M, Takeishi $\mathrm{T}$, Thompson $\mathrm{H}$, et al. Induction of mast cell proliferation, maturation, and heparin synthesis by the rat c-kit ligand, stem cell factor. Proc Natl Acad Sci USA 1991; 88(14): 6382-6.

[22] Mencia-Huerta JM, Lewis RA, Razin E, Austen KF. Antigeninitiated release of platelet-activating factor (PAF-acether) from mouse bone marrow-derived mast cells sensitized with monoclonal IgE. J Immunol 1983; 131(6): 2958-64.

[23] Schwartz LB, Austen KF, Wasserman SI. Immunologic release of beta-hexosaminidase and beta-glucuronidase from purified rat serosal mast cells. J Immunol 1979; 123(4): 1445-50.

[24] Hamon M, Fattaccini CM, Adrien J, Gallissot MC, Martin P, Gozlan $\mathrm{H}$. Alterations of central serotonin and dopamine turnover in rats treated with ipsapirone and other 5-hydroxytryptamine1 A agonists with potential anxiolytic properties. J Pharmacol Exp Ther 1988; 246(2): 745-52.

[25] Abraham SN, Malaviya R. Mast cells in infection and immunity. Infect Immun 1997; 65(9): 3501-8.

[26] Abraham SN, Arock M. Mast cells and basophils in innate immunity. Semin Immunol 1998; 10(5): 373-81.

[27] Galli SJ, Maurer M, Lantz CS. Mast cells as sentinels of innate immunity. Curr Opin Immunol 1999; 11(1): 53-9.

[28] Marone G. Mast cells in rheumatic disorders: mastermind or workhorse? Clin Exp Rheumatol 1998; 16(3): 245-9.

[29] Wershil BK. Role of mast cells and basophils in gastrointestinal inflammation. Chem Immunol 1995; 62: 187-203.

[30] Dobrowolski JM, Sibley LD. Toxoplasma invasion of mammalian cells is powered by the actin cytoskeleton of the parasite. Cell 1996; 84(6): 933-9.

[31] Pelloux H, Ricard J, Bracchi V, Markowicz Y, Verna JM, Ambroise-Thomas P. Tumor necrosis factor alpha, interleukin 1 alpha, and interleukin 6 mRNA expressed by human astrocytoma cells after infection by three different strains of Toxoplasma gondii. Parasitol Res 1994; 80(4): 271-6.
[32] Henderson WR, Jr., Chi EY. The importance of leukotrienes in mast cell-mediated Toxoplasma gondii cytotoxicity. J Infect Dis 1998; 177(5): 1437-43.

[33] Field MC, Medina-Acosta E, Cross GA. Characterization of a glycosylphosphatidylinositol membrane protein anchor precursor in Leishmania mexicana. Mol Biochem Parasitol 1991; 48(2): 227-9.

[34] Soteriadou KP, Remoundos MS, Katsikas MC, et al. The Ser-ArgTyr-Asp region of the major surface glycoprotein of Leishmania mimics the Arg-Gly-Asp-Ser cell attachment region of fibronectin. J Biol Chem 1992; 267(20): 13980-5.

[35] Grimwood J, Smith JE. Toxoplasma gondii: the role of a 30-kDa surface protein in host cell invasion. Exp Parasitol 1992; 74(1): 106-11.

[36] Channon JY, Suh EI, Seguin RM, Kasper LH. Attachment ligands of viable Toxoplasma gondii induce soluble immunosuppressive factors in human monocytes. Infect Immun 1999; 67(5): 2547-51.

[37] Furtado GC, Slowik M, Kleinman HK, Joiner KA. Laminin enhances binding of Toxoplasma gondii tachyzoites to J774 murine macrophage cells. Infect Immun 1992; 60(6): 2337-42.

[38] Bianchine PJ, Burd PR, Metcalfe DD. IL-3-dependent mast cells attach to plate-bound vitronectin. Demonstration of augmented proliferation in response to signals transduced via cell surface vitronectin receptors. J Immunol 1992; 149(11): 3665-71.

[39] Ducharme LA, Weis JH. Modulation of integrin expression during mast cell differentiation. Eur J Immunol 1992; 22(10): 2603-7.

[40] Dastych J, Metcalfe DD. Stem cell factor induces mast cell adhesion to fibronectin. J Immunol 1994; 152(1): 213-9.

[41] Vliagoftis H, Metcalfe DD. Characterization of adhesive interactions between mast cells and laminin isoforms: evidence of a principal role for alpha 6 integrin. Immunology 1997; 92(4): 553-60.

[42] Foussard F, Leriche MA, Dubremetz JF. Characterization of the lipid content of Toxoplasma gondii rhoptries. Parasitology 1991; 102 Pt 3: 367-70.

[43] Martin TW, Lagunoff D. Interactions of lysophospholipids and mast cells. Nature 1979; 279(5710): 250-2.

[44] Hara N, Murakami M, Inoue K, Kudo I. Lysophosphatidylserine enhances exogenous type II phospholipase A2-induced activation of rat serosal mast cells. Biol Pharm Bull 1996; 19(3): 474-6.

[45] Monastra G, Pege G, Zanoni R, Toffano G, Bruni A. Lysophosphatidylserine-induced activation of mast cells in mice. J Lipid Mediat 1991; 3(1): 39-50.

[46] Murakami M, Umeda M, Kudo I, Inoue K. Change in sensitivity to lysophosphatidylserine of mouse bone marrow-derived mast cells during cultivation with fibroblasts. Int Arch Allergy Appl Immunol 1991; 96(2): 156-60.

[47] Ramos BF, Qureshi R, Olsen KM, Jakschik BA. The importance of mast cells for the neutrophil influx in immune complex-induced peritonitis in mice. J Immunol 1990; 145(6): 1868-73.

[48] Del Rio L, Bennouna S, Salinas J, Denkers EY. CXCR2 deficiency confers impaired neutrophil recruitment and increased susceptibility during Toxoplasma gondii infection. J Immunol 2001; 167(11): 6503-9.

Received: March 17, 2008

Revised: April 28, 2008

Accepted: April 30, 2008

(C) Bidri et al.; Licensee Bentham Open.

This is an open access article distributed under the terms of the Creative Commons Attribution License (http://creativecommons.org/licenses/by/2.5/), which permits unrestrictive use, distribution, and reproduction in any medium, provided the original work is properly cited. 